\title{
Karadžić's guilty verdict and forensic evidence from Bosnia's mass graves
}

\begin{abstract}
The International Criminal Tribunal for the Former Yugoslavia's Karadžić verdict, eagerly awaited, was unsurprising. He was found guilty of genocide, crimes against humanity and war crimes. One part of the judgment was concerned with the Srebrenica events in which much forensic evidence from mass graves featured. Whilst this was to be expected, forensic evidence from the horrific crime scenes continues to be important in determining aspects of the crime base. This paper discusses the evidence and examines how the Chamber came to the conclusion that systematic killing of thousands of Bosnian Muslim men occurred and attempts had been made to conceal the crimes and human remains in secondary graves thus confirming the actus reus of genocide. In particular, the number of people killed was at issue. Despite the absence of compelling counter-theories on behalf of the accused, this paper demonstrates that contestations over the number of those killed remain and predicts that this is unlikely to change for the ongoing Mladić case.
\end{abstract}

\section{Highlights:}

- Karadžić's guilty verdict features much forensic evidence from Srebrenica massacre.

- Forensic evidence from mass grave confirms the act of genocide.

- Numbers of those killed as well as time and manner of death remain contested by the accused.

Keywords: mass graves; forensic evidence; expert evidence; international criminal proceedings; International Criminal Tribunal for the Former Yugoslavia; International Criminal Court

\section{Introduction}

Reactions to the Radovan Karadžić judgment were quick and highly anticipated. The media coverage from the International Criminal Tribunal for the Former Yugoslavia (ICTY) suggested a certain frenzy about a guilty verdict everyone expected. The judgment in this 
landmark case of the highest ranking official to be tried in the 23-year long history of the ICTY confirms the atrocities committed in Bosnia's war from 1992-1995. Of the eleven counts that Mr. Karadžić was indicted for, he was found not guilty on the first count of genocide in certain Municipalities, but guilty for all the other ten counts, including: genocide in Srebrenica; persecution, extermination, murder; deportation and inhumane acts of forcible transfer as crimes against humanity; as well as murder, terror, unlawful attacks on civilians and hostage taking as violations of the laws or custom of war.[1] In short, the guilty verdict for genocide, crimes against humanity and war crimes resulted in a 40-year sentence for the former Bosnian Serb leader.

Reports on the mood in Bosnia speak of "mixed reactions"[2] to this judgment with "political and ethnic divisions ... on display"[3]. From the field of transitional justice one commentator suggests that whilst the verdict identifies Radovan Karadžić as utilising extermination, torture, rape, forced deportation and persecution as a way to create an ethnically pure Serb state within the territory of Bosnia at the costs of Bosnian Muslims and Croats, "the fruits of his bloody labor ... are alive and flourishing."[4] A political science expert also points to the divided reception of this judgment: On the one hand, it provides an evidence based link between Karadžić's policy and the destruction, death and suffering amidst the conflict. On the other hand, Karadžić continues to be revered as a national hero by Bosnian Serbs who "had pre-emptively contested a guilty verdict, as well as the legitimacy of the international court, which they see as an anti-Serb instrument."'5] International criminal commentators were also quick to offer thoughts questioning the length of the trial, from charging strategy, over case management on behalf of the judges, to the value of a 2,615 page strong judgment putting into doubt the "usefulness of international judgments generally"[6]. Rather worryingly, this includes the thought that acquittals may not be an option if there is such great expectation worldwide for a conviction.[7]

For a conviction on the grounds of genocide, crimes against humanity and war crimes the prosecution has to prove a catalogue of things. To qualify as the crime of genocide the accused must have deliberately intended "to destroy, in whole or in part, a national, ethnical, racial or religious group as such.”[8] Punishable under Article 4(3) are also conspiracy to commit genocide, incitement to commit genocide, attempts to commit genocide and complicity in genocide.[9] The actus reus, that is the killings, causing serious bodily or mental harm to members of the group and deliberate infliction of conditions designed to 
bring about the destruction of the group and the mens rea, the specific intent to destroy the group as such, in whole or in part, have to be proven. Where direct evidence of genocidal intent is absent, the requisite intent may be inferred from the factual circumstances of the crime. Of particular interest for the discussion in this paper, is the way in which the determination of "part" of the group is arrived at. According to the International Court of Justice, "the intent must be to destroy a substantial part of the particular group."[10] In other words, a quantitative assessment of the destruction of the group is required to ascertain the substantiality criterion, which is why the Trial Chamber in Karadžić spends much effort on determining the number of those killed. Genocide might occur in a geographically limited area as "it is not necessary to intend to achieve the complete annihilation of a group from every corner of the globe."[11] In addition, ICTY jurisprudence has determined that " $[\mathrm{t}] \mathrm{he}$ number of individuals targeted should be evaluated not only in absolute terms, but also in relation to the overall size of the entire group. In addition to the numeric size of the targeted portion, its prominence within the group can be a useful consideration. If a specific part of the group is emblematic of the overall group, or is essential to its survival, that may support a finding that the part qualifies as substantial within the meaning of Article."[12] Crimes against humanity require that an attack directed against any civilian population must have occurred and that the attack must be widespread or systematic.[13] Furthermore, the perpetrator must be part of the attack and have knowledge of the attack and knowledge of his part in the attack.[14] To qualify as an Article 3 violation, murder, unlawful attacks on civilians, terror and taking of hostages has to be proven as acts contrary to the laws or customs of war.[15]

Naturally, over the coming weeks, months and years, further discussion and reactions to this case will follow not least since an Appeal to the Trial Chamber judgment is highly likely, possibly focusing on the issue of (in)sufficient evidence for genocidal intent for count one of the charges. What is, however, quite apparent are the differing receptions the judgment has already had, prompting this paper to revisit the suggestion made that, for the Srebrenica events, forensic evidence is believed to have prevented revisionists from continuing to publicise that the crimes had not been committed.[16] So what did forensic science from mass graves contribute to the Karadžić Judgment?

There is much to dissect and discuss: The Trial Chamber sat for 499 days, 11,469 exhibits were tendered into evidence and the trial record total stands at over 330,000 pages.[17] The 
Prosecution under Rule 94 bis [18] on the testimony of expert witnesses, which provides a timetable for disclosure and other preliminaries, called 19 expert witnesses, the defence called nine. For the purpose of the ICTY, although not explicitly defined, an expert witness is someone who possesses the relevant specific knowledge, experience or skills to help the Trial Chamber come to a better understanding and conclusion on a technical issue.[19] The qualifications of an expert, summarised in the expert's curriculum vitae submitted to the court, authorise the expert - unlike an ordinary witness of fact - to state opinions, inferences and conclusions on matters within the realm of her expertise. Whilst some of the experts were historians, demographers and military analysts, of interest to this paper are the forensic experts in anthropology, pathology, archaeology and DNA identification. The Trial Chamber itself notes that it "refers in particular to the detailed section on the forensic, demographic, and DNA evidence in relation to the Srebrenica component of the case.'[20] This paper follows its lead and focuses on the forensic evidence from mass graves surrounding the Srebrenica events. Though it is worth noting that forensic exhumations of mass graves were also conducted in other areas of Bosnia under the auspices of the ICTY's investigations (as well as in Croatia and Kosovo).[21] Information contained in pathologist Dr. John Clark's report on the Paklenik Cave relating to the human remains of 73 Bosnian Muslim men, for example is also included in the judgment as valuable evidence to determine the charges against the accused in relation to the municipality of Višegrad.[22] After an examination of the forensic findings regarding the Srebrenica events contained in the judgment, this paper analyses the contested elements of those Trial Chamber determinations before concluding with an outlook on what to expect from the Mladic case and proceedings before the International Criminal Court (ICC) in terms of forensic findings.

\section{Volume IV of the Judgment - the Srebrenica events}

The events that occurred in and around the Srebrenica enclave, in particular between the days of 10 and 19 July 1995, have been well documented[23] and despite the presence of UNPROFOR (United Nations Protection Force) the atrocities culminated in the "biggest single mass murder in Europe since the Second World War.'[24] A key element of the charges brought by the prosecution, Karadzić stands accused for his involvement in implementing and orchestrating the forcible transfer and eventual elimination of the Bosnian 
Muslim population from Srebrenica. These killings of Bosnian Muslims during July and August 1995 are the underlying act of genocide charged under Count two.[25]

Reportedly, forensic investigations into the Srebrenica massacre assisted in indicting Radovan Karadžić, General Ratko Maldić, whose trial at the ICTY is ongoing, and General Radislav Krstić[26] (a case much referred to in the Karadžić judgment), who has since been convicted for aiding and abetting genocide.[27] For the Srebrenica investigations, between 1996 and 2001, ICTY exhumations were conducted at 23 sites, whilst a further 20 mass graves were probed to confirm that they contained human remains.[28] The investigative objectives for these investigations were to:

- corroborate victim and witness accounts of the massacres;

- determine an accurate count of victims;

- determine cause and time of death;

- determine the sex of victims;

- determine the identity of victims (a process that is ongoing with the help of DNA analysis); and

- identify links to the perpetrators.[29]

The task of locating and exhuming mass graves in Bosnia is ongoing, as is the general quest of locating the missing in the territory of the former Yugoslavia. This work was and is continued through organisations such as the Bosnia and Herzegovina Commission on Missing Persons (BiHCMP) followed by the International Commission on Missing Persons (ICMP).[30]

Through the ICTY's Rule 94 bis on the testimony of expert witnesses, evidence is tendered and expert reports admitted, with the Rule providing a timetable for disclosure and other preliminaries.[31] At this stage, the opposing party has to indicate whether it intends to accept the expert witness report, wishes to cross-examine the expert witness, disputes her qualifications or contests the relevance of the witness statement. Admissibility of expert evidence can be denied on grounds of unreliable methods[32]; issues of fairness of the trial[33]; or lack of probative value[34]. If no objection is made by the other side, a scientific report can be admitted into evidence without hearing testimony from the expert, so long as the Trial Chamber is satisfied that the evidence is both relevant and has probative value.[35] As will be 
discussed below, challenges based on the expert's methods of data collection and whether, in light of the way the scientific inquiry was conducted, its results are reliable, are common.

There are also rules to facilitate expeditious presentation of complex scientific evidence. Rule 92 bis authorises the presentation of summary reports by investigators in relation to mass grave excavations and examinations. These summary reports, many of which the Chamber relied on and refers to in the Karadžić judgment, are compilations derived from multiple sources, containing background evidence of the forensic examinations, contextualising and reducing the complexity of the findings.[36] Whilst summary reports can save precious trial time, they may be challenged as hearsay evidence, which is generally admissible in international criminal proceedings but may be accorded little probative value.[37] However, such reports on physical evidence recovered from Srebrenica execution points and mass graves used in Krstić were subsequently also found to be "highly relevant to the case and admissible under Rule 89"[38] in Blagojević and they are referred to frequently in the present judgment[39]. Similarly, Rule 92 bis (D) authorises the admission of trial transcripts of evidence previously given by a witness, including expert witnesses, provided the evidence does not relate to the acts and conduct of the accused. In the Karadžić trial, statements and transcript testimony of numerous experts relating to mass grave investigations were admitted in this way and cited in the judgment's footnotes. This paper concentrates on the Trial Chamber's interpretation of these numerous types of evidence (trial transcripts, expert reports, expert testimony, exhibits and judicial decisions) as opposed to the individual evidence submissions themselves, since the Chamber relies on evidence in its entirety. The analysis is focused on the Trial Chamber's findings because it cannot always be determined with certainty which of the often numerous sources listed in the footnotes was determinative of a particular decision. However, the discussion does take recourse, where appropriate, to the summary reports offered by ICTY investigators Dean Manning and Dušan Janc, as well as ICMP reports on DNA, since sections of the judgment are dedicated to this specific evidence.[40]

\subsection{Forensic evidence: Sites and Findings}

In the judgment itself, forensic science features most prominently in relation to the following sites and events. The list below is somewhat unsurprising as much of this evidence has also been relied upon in the Kristić, Popović et al. and Tolimir trials but some new insights, especially through DNA analysis, have been added. As discussed, a central question was how many were killed systematically in the Srebrenica events. 
Forensic evidence from mass graves was referred to with regards to a BiHCMP exhumed gravesite near the Sandići Meadow where 17 individuals who had been reported missing after the fall of Srebrenica were identified, based on DNA analysis, from the human remains located at the gravesite. Whilst the Chamber was not able to confirm the connection between the grave and an alleged killing at the Meadow as per the indictment, it found that on 13 July 1995 "approximately 10 to 15 Bosnian Muslim men from Srebrenica were killed at the Sandići Meadow by members of the Bosnian Serb Forces.'[41] For another investigation conducted by BiHCMP into a grave site connected to killings at Luke School near Tišća, it was confirmed that 15 individuals from that examination had been positively identified as persons on the missing list following the Srebrenica take-over.[42]

The primary gravesite at Cerska Valley had been investigated between 7 and 18 July 1996 by Physicians for Human Rights under William Haglund's lead. In an updated report of 2012 on the summary of forensic evidence relating to Srebrenica, DNA analysis reveals that 144 of the bodies exhumed in this 1996 operation were listed as missing after the Srebrenica events.[43] But the Chamber did not fully agree with the Prosecution's claim nor Dr. Haglund's report that all 150 victims found in the grave were subject to one single execution at Cerska Valley. Additional evidence received by the Chamber, showed that "a large number of victims found in the Cerska gravesite were last seen alive on various dates on or after 13 July, including as late as August 1995."[44] Based on this discrepancy with the initial prosecution claim that the killing and subsequent burial at Cerska took place on 13 July 1995, the Chamber felt unable to make a determination on the time the killings took place and whether bodies were buried in the grave without prior execution at that site. Taking into account information suggesting that a number of victims had been seen alive after 17 July 1995 in different locations, the Chamber noted an inconsistency between the number of victims and the recorded date and place of their disappearance for almost a third of the 150 exhumed victims. It therefore cautiously stated that whilst it was "satisfied that at least some of the bodies exhumed from the Cerska gravesite were victims of execution, the Chamber is unable to make a finding as to how many or when they were killed."'[45] In other words, since corroboration of forensic evidence as to the circumstances and time of the killings was not available to the Chamber and with evidence pointing at differing accounts to the one included in the indictment, the Chamber had little choice but to not make a determination on numbers. 
Forensic Evidence also featured with regards to the Kravica Warehouse killings and the gravesites near the village of Glogova which demonstrated a physical link between the gravesites and the warehouse.[46] Exhumed in part by a team under the direction of Richard Wright and then subsequently analysed in a morgue under the direction of Dr. John Clark, they found that all the victims at Glogova were male, between the age of 12 and 75 with most bodies presenting gunshot wounds. Shrapnel injuries were also found in $21 \%$ of the bodies with 12 of the exhumed victims having been bound by ligatures and killed by a gunshot to the head.[47] Crucially, the Glogova gravesites showed evidence of disturbance with bodies having been removed by machinery, leaving dismembered body parts behind. The resulting secondary mass graves were then discovered along the Zeleni Jadar Road, at Budak, Blječeva, Zalažje and Ravnice. In relation to Zeleni Jadar graves 5 and 6, which were investigated under the direction of Richard Wright in 1998 and José Pablo Baraybar in 2001, the Chamber was satisfied with evidence suggesting that bodies were taken from Glogova gravesites to the secondary graves in Zeleni Jadar.[48] Similaly DNA analysis from investigations into the Budak, Blječeva and Zalažje graves demonstrated connections to the Glogova sites. Furthermore the DNA profiles were consistent with 326 victims listed as missing persons following the Srebrenica take-over.[49] The Ravnice site, however, differed from the other gravesites as a number of bodies were not buried in the ground but rather scattered on the ground.[50] Victims from Ravnice were male, the vast majority showed multiple gunshot injuries with no convincing evidence of serious injury as a result of shrapnel pertaining to grenades or other projectiles.[51] On the missing persons list following the Srebrenica events were 206 victims from Ravnice.[52] In an attempt to piece together the array of evidence pertaining to the Kravica Warehouse incident, Glogova site and corresponding secondary graves, the Chamber found that "on 13 July 1995, between 755 and 1,016 Bosnian Muslim men were killed by members of the Bosnian Serb Forces at the Kravica Warehouse.’[53]

Primary, but disturbed, gravesites of Lazete are located close to the village of Orahovac. Lazete 1 was partially excavated in 2000 under the direction of Fredy Peccerelli and examined by a team under the leadership of John Clark. Despite the removal of bodies through machinery causing disarticulation of human remains, 130 bodies and 15 body parts were found in the grave.[54] For at least $97 \%$ of the victims, gunshot injuries were determined as the cause of death.[55] A total of 138 blindfolds were found; some had bullet 
holes indicating that a number of the victims were blindfolded when shot. None of the victims wore military clothing.[56] A similar pattern was discerned from exhumations at the Lazete 2 gravesite in 1996 and 2000. The grave contained male victims, blindfolds but no military clothing.[57] The corresponding seven secondary graves were located along the Hodžići road. Aearial images suggests they were created between 7 September and 2 October 1995[58] and soil samples, identical blindfolds and other artefacts link the Hodžići graves to the Lazete ones.[59] Importantly, DNA analysis too confirms the connection. Overall, the chamber found that, "at least 839 Bosnian Muslim men being detained at the Orahovac School were killed in a field nearby by members of the Bosnian Serb Forces"[60] before being disposed into mass graves which were subsequently disturbed.

This pattern of primary and secondary graves was also established for the Petkovci Dam site and secondary graves relating to the Dam that were found in Liplje Road. Again, a combination of forensic excavation, examination of body parts, artefacts, soil samples and DNA confirmed the link. However, due to disturbances and decomposition, no cause of death for the remaining body parts was offered by the forensic experts.[61] Nonetheless, the Chamber found that "on 14 and 15 July 1995, at least 815 Bosnian Muslim men detained at the Petkovci School were killed by the Bosnian Serb Forces. Some were summarily executed by the Bosnian Serb Forces while being detained at Petkovci School. The rest were killed in a field nearby the Petkovci Dam."[62]

The Kozluk gravesites too are an example of primary graves, with Kozluk 2 and 3 also being sites of execution, whilst the corresponding secondary graves were found in Čančari Road. Of the total 13 secondary graves on Čančari Road, five were linked to the Kozluk primary gravesite.[63] While the cause of death was not always possible to discern, for 29 complete bodies gunshot wounds were identified as the cause of death and injuries in the majority of cases was consistent with gunshot wounds. DNA connections, pieces of broken green bottles, soil and shell case analysis determined the link between the graves.[64] Once more the Chamber found that a minimum of 815 Bosnian Muslim Men had been killed either at the detention point at the Ročević School or at the site of the Drina River near Kozluk.[65]

Another part of the indictment refers to the killing of 500 Bosnian Muslim men at the Pilica Cultural Centre with the victims buried at the Branjevo Military Farm.[66] In an attempt to conceal the killings, the bodies were then taken from Branjevo Military Farm and buried at 
some of the Čančari Road secondary graves. Whilst the Branjevo Military Farm gravesite, measuring 28 meters by 10 meters with a depth of 3 meters, was excavated in September 1996, the corresponding Čančari Road Graves (4-6, and 8-12) were probed in 1998.[67] One grave, Čančari Road 12, was excavated under the auspices of Richard Wright, whilst the remaining sites were handed over to the $\mathrm{BiH}$ government. At Čančari Road 12, the remains of a minimum of 177 individuals were found. Where sex determination was possible, it could be determined as male. And from the 43 complete bodies found, 39 had died of gunshot wounds. Injuries of the majority of body parts was also consistent with gunshot wounds.[68] DNA evidence too confirmed the link between the primary and secondary graves.[69] Whilst the Chamber found that some of the Bosnian Muslim men were killed at another site, the Kula School, they found that "about 1,200 were killed at the Branjevo Military Farm, and about 500 were killed at the Pilica Cultural Centre.’[70]

Reviewing and considering the evidence presented to the Chamber it "found that at least 5,115 men were killed by members of the Bosnian Serb Forces in July 1995 in Srebrenica."[71] What this exposition demonstrates, is that the prosecution, through the use of forensic evidence, wished to prove a number of key aspects to confirm the crime of genocide, war crimes and crimes against humanity.[72] In particular for the crime of genocide, as discussed in the introduction, the accused must have deliberately intended to destroy a protected group (ethnic, national, racial, or religious) in whole or part.[73] The evidence discussed in this section does assist in this regard: Crucially it confirms that a specific group, Bosnian Muslim men, was targeted in great numbers. It therefore satisfies Article 4(2)(a), the killing of members of the group, as well as causing serious bodily and mental harm under Article 4(2)(b), but also impacts upon a group's ability to procreate.[74] Importantly, a determination of numbers helps to satisfy the substantiality requirement of genocide. The forensic evidence points to a significant number of people pertaining to one group being killed within a geographically limited area. The Chamber, referring to the Krstić Appeal Judgment[75], found that "although the Bosnian Muslim population in Srebrenica constituted a numerically small percentage of the Bosnian Muslim population, the enclave's seizure was of particular strategic importance due to its geographic proximity to Serbia, its symbolic stature as a refuge for Bosnian Muslims, and the fact that its elimination despite its status as a safe area would be demonstrative of the potential fate of all Bosnian Muslims.’[76] 
Furthermore, the discernable pattern of detention in schools or centres, followed by many execution style killings and the resulting burials, points to a systematic operation. The age range of victims found in the graves, including young children and elderly, coupled with evidence that no military clothing and little injuries consistent with combat injuries were discernable, suggest that many civilians were amongst the dead. Given the number of links between primary and secondary graves, demonstrable attempts had been made to conceal the crimes, suggesting also that a high level of coordination and cooperation was required to undertake such executions, burials and re-burials. Through continued DNA analysis and identification efforts, DNA confirmed that many victims found in the graves were those that had gone missing following the Srebrenica take-over. This evidence is also central to confirm crimes against humanity and war crimes through outlining that those found in mass graves had not been killed legitimately in combat but were civilians instead whose murder would constitute a crime against humanity and a war crime. Murder, extermination and persecutions on political, racial and religious grounds form part of crimes against humanity[77], whilst wilful killing is punishable as a grave breach of the Geneva Conventions[78].

\subsection{Contestations}

Expert evidence presentation at the ICTY follows the following pattern. After the solemn declaration, examination-in-chief begins with a discussion of the expert's education and qualifications, employment record and relevant experience, before substantial matters relating to the scientific report are queried to demonstrate the credibility of the witness and the reliability of the evidence presented. Cross-examination by the opposing party then follows and, if necessary, re-examination by the party who initially called the expert. In light of the technical nature of the evidence, the accused can request the presence of her own expert during such testimony to assist with cross-examination[79], which Mr. Karadžić did by employing defence expert Dušan Dunjić who had testified before at the ICTY.[80]

Whilst much of the forensic evidence presented by the prosecution was found reliable, the Chamber note objections on methodology voiced by defence expert Dušan Dunjić. One of the most contested issues surrounding the Srebrenica events is the number of victims killed in July 1995. The Prosecution supports its claim that over 7,000 Bosnian Muslim men and boys were killed by referring to the 5,850 identified bodies following forensic investigations, excavations, examinations and identification efforts.[81] In contrast, the accused contends 
that approximately 4,000 persons are unaccounted for.[82] He claims that the Chamber is not in a position to make a finding beyond reasonable doubt on the numbers of victims killed, firstly because the date of death had not been established and secondly because the cause and manner of death could not always be ascertained.

\subsubsection{Date of Death}

With regards to the time of death, the accused argues that the individuals may have died during the course of combat between 1992 to 1995 and not specifically between 12 and 23 July 1995 as per the indictment. He claims the graves excavated may have contained bodies of those killed over a period of 45 months. [83] Defence expert Dunjić concluded that a precise date of death could not be determined - a finding that is supported by prosecution experts who had conducted the investigations due to, for example, varying degrees of decomposition.[84]

Additionally the accused alleges bias on behalf of the prosecution experts since they had been told prior to their work in the field that they were exhuming bodies of men who had been executed following the fall of Srebrenica.[85] The debate about the level of information required by forensic teams to conduct their work has been discussed in the literature. More background information may imply a greater involvement with the prosecution's strategies but may enhance the quality of investigation by raising the experts' awareness of details and potential evidence.[86] The Judgment points to debates in court where experts were asked abut the level of information provided to them, leading the judges to conclude that "the fact that experts were provided with limited background information about the bodies in the gravesites and, more generally, about the fall of Srebrenica, does not, in and of itself, taint their reports with bias or make them less reliable.'[87] This is consistent with other jurisprudence on expert witnesses. Though qualifications are a formal prerequisite for expert witnesses, objectivity and independence are not. Instead, "the questions of objectivity, impartiality and independence become relevant to assess the weight to be accorded to that opinion evidence.'[88] Similarly, affiliation with a party does not in itself constitute grounds for disqualification. The examples discussed above where the BiHCMP conducted exhumations, may point to the conclusion that clear affiliation with the prosecution, for criminal purposes at least, is desirable. Investigations under the auspices of the Prosecution can provide a clearer and more complete picture of the entire crime scene, connecting detention, execution and graves through forensic evidence retrieved at each site. 
The theory of mixed mass graves where bodies were buried at different times in the same grave was also proffered as a means to justify a lesser number of Srebrenica victims. Victims in the same grave may not have died on the same day or at the same place but instead may have died at different sites and then been buried in the same mass grave. This theory of "enrichment" (a term used in the judgment by reference to the defence expert's opinion)[89] is not supported by archaeological evidence at the sites nor were there signs that bodies had been buried as part of the sanitation process. The prosecution contests this defence theory on six grounds: there was no evidence to suggest the victims had died in combat; the Srebrenicarelated graves did not show signs of having been created at existing burial sites or re-opened sites; evidence into the cause and manner of death suggests executions at the primary grave sites; blindfolds and ligatures were found in graves associated with killing sites; artefacts were found linking victims to detention and execution sites; and finally, there was also no credible evidence to suggest secondary graves contained bodies other than those of victims from primary graves.[90] Experts confirmed that "blindfolds were not bandannas"[91] but in fact had been tightly tied on the eyes.

In addition, the accused views the various degrees of decomposition as supporting his theory that victims had died prior to the fall of Srebrenica suggesting different times of death. Evidence to this effect was presented by the defence expert[92] whilst the prosecution experts testified that many factors are involved in affecting decomposition of bodies.[93] This led the Chamber to conclude that, whilst differing degrees of decomposition might point to different burials times, the totality of the evidence presented regarding the Srebrenica related gravesites would suggest that "the existence of various degrees of decomposition within a single gravesite is not indicative of various times of burial and/or of various dates of death.’'[94]

Finally, the accused claimed that multiple layers of clothing present on bodies found in the graves would suggest they died in winter as opposed to in July, the midst of summer. This suggestion, however, was dismissed by the chamber as evidence had been presented to the chamber of people fleeing Srebrenica wearing multiple layers of clothing.[95]

\subsubsection{Cause and manner of death}

Another objection by the accused and his defence expert came with regards to the cause and 
manner of death, especially as prosecution expert John Cark had acknowledged that perimortem injuries may be difficult to distinguish from postmortem damage.[96] Furthermore, evidence of gunshot injuries was assumed to, in the majority, have occurred in life. Where bullets, however, passed through limbs, and in the absence of other fatal wounds, the cause of death could not be ascertained.[97] Defence expert Dunjić criticised the summary reports offered by the forensic experts as lacking in detail and analysis, thus failing to establish injuries were, in fact, gunshot injuries. He claims that determinations on the cause and manner of death were erroneously arrived at, accusing one of the prosecution experts of making "arbitrary, if not actually malicious" findings.[98] The Chamber, however, does find no support for the defence expert's views accusing him, in turn, of looking at information in isolation.[99]

\subsubsection{Determining numbers}

In addition to the forensic evidence from mass graves, the Chamber also heard evidence from ICMP in relation to DNA identification.[100] ICMP works towards positive identifications through extracting DNA from skeletal remains or blood samples and performing a polymerase chain reaction amplification of the short tandem repeat locus. A positive match requires a minimum of $99,95 \%$ certainty. Whilst Mr. Karadžić, for confidentiality reasons, had no access to the entire ICMP database, a sample of 286 cases for which consent had been granted, was offered to be made available to him. The accused refused this offer to test selected cases, filing instead a motion to exclude ICMP's DNA analysis, a motion which was denied.[101] Whilst Mr. Karadžić did not present expert evidence challenging either the methodology or results of the ICMP, during the expert witness testimony he sought to discredit the expert alleging also bias due to the nature of funding and support ICMP receives, thus suggesting a clear partiality on political grounds.[102] The Chamber, however, believes "the ICMP to be a reputable, impartial and reliable institution."[103] In addition, this data from ICMP was cross-referenced for connections between gravesites. Since dismembered body parts may be present in multiple graves, it is important not to count the same individual more than once. As a result of this process the figure of 5,977 total number of individuals was identified in Srebrenica related gravesites (as of January 2012).[104]

Examining the data, the Chamber found significant overlap between the 5,977 individuals in the 2012 report and its number of 5,115 individuals following the assessment of forensic evidence presented during the trial (see above). Furthermore, and in light of the totality of 
evidence presented by survivors and insiders, forensic, demographic and DNA evidence, "the Chamber is satisfied that there is no evidence that primary or secondary gravesites were enriched."[105] The discussion above demonstrates that not all the numbers and aspects of the forensic evidence offered were wholesale integrated into the Chamber's findings, but much of the forensic evidence has been accepted as reliable by the Chamber, especially when corroborated by other information. Whilst the Prosecution might perceive the Chamber's approach to number as too conservative, the defence has argued the opposite. That said, a detailed, yet stringent, discussion along the lines of the indictment and alleged crimes is offered, with forensic evidence contributing, for the most part, convincing, useful and dependable information.

\section{On numbers and "bandannas" - there is more forensic evidence to come at the ICTY and ICC}

At the ICTY's trial of Ratko Mladić, who stands accused of two counts of genocide, five counts of crimes against humanity and four counts of war crimes, there are more findings on forensic evidence from mass graves to come. The appearance by forensic pathologist Dr. John Clark in the Mladić trial, testifying about hundreds of bodies exhumed from the Tomašica mass grave near Prijedor, would suggest this.[106] Defence tactics offered by Belgrade based forensic expert Zoran Stanković are remarkably similar to what was seen in the Karadžić trial: In Stanković's assessment as to why 39\% of victims from the Tomašica grave were skeletonized, he indicates they might have been in the open and died at a different time. Similarly, Stanković's testimony whishes to advance the theory that victims died in combat as opposed to having been executed. For him, who also has military experience, injuries to head and chest are entirely consistent with combat given that those body areas of the enemy would be targeted in order to result in lethal injuries. But Dr. Stanković had to concede, on being asked by Judge Moloto, that these injuries are also consistent with mass executions.[107] In court the "bandanna" theory on BiH army soldiers habitually wearing bandannas surfaced again with Dr. Haglund also coming under fire for his work at mass graves. Notably, though Haglund's approach may have been criticised, the results from his work for the ICTY had not been discredited. Interestingly, in this latest display of counterexpertise, no new defence strategies are apparent. The same "time of death" and "cause of death" alternate hypotheses are proffered. Whether this time round they will be more successful, is highly doubtful (though surprise decisions by ICTY Chambers cannot entirely 
be excluded, as the latest, highly controversial, Šešelj acquittal[108] has demonstrated). Whichever way the Mladic decision will go, and there is no real reason to suggest the findings will differ from the assessment in Karadžić, on the ground in Bosnia Herzegovina and Serbia, judicial interpretation of facts remains highly disputed.

The same week of the Karadžić judgment, a second international criminal case came to a close: that of Jean-Pierre Bemba Gombo at the International Criminal Court (ICC), the permanent institution to adjudicate on international crimes.[109] Bemba's case too received wide coverage as he was found guilty on two counts of crimes against humanity for murder and rape and three counts of war crimes, that is murder, rape and pillaging. Interestingly, the ICC has a slightly different approach to expert witnesses and due to the different situations, cases and crimes investigated, to date, forensic expertise of the kind presented in the Karadžić trial has not featured. Like the ICTY, the ICC adopts a flexible approach to the admissibility of evidence. Under article 69 of the Rome Statute "[t]he Court shall have the authority to request the submission of all evidence that it considers necessary for the determination of the truth."[110] With regards to evidence, including expert evidence, the Court adopts the affirmative, as opposed to exclusionary, method of evidence admission, taking into account in particular the probative value of the evidence and whether it is prejudicial to fair trial requirements.[111] Pursuant to Regulation 44(1) the Registry holds a list of experts whose qualifications have been verified and "have undertaken to uphold the interests of justice"[112]. Where possible, the parties are expected to rely on this list for expert instructions. To facilitate efficient trial management, joint instructions (including by victim representatives) of expert witnesses are preferred.

In the setting of the ICC, the use of expert witnesses was suggested as a potential avenue to avoid or contextualise reliability issues of witnesses, especially victims who testify as witnesses. To portray the context and background evidence surrounding the offences better, an expert witness may be a useful option to provide evidence, including, where appropriate, on the psychological and physical suffering victims have endured, from a position of neutrality.[113] In fact, in a recent testimony by forensic psychologist John Charles Yuille in the Bosco Ntaganda[114] trial, his testimony was to provide the judges with a better understanding as to how trauma can affect individuals, especially memory patterns and how trauma may result in amnesia. In that sense, forensic evidence retains a vital importance for international criminal proceedings. 


\section{Conclusion}

Returning to commentary offered shortly after the Karadžić judgment, Refik Hodzic's account of reactions to the verdict at Belgrade University are most alarming. In his piece he speaks of laughter by University students in Belgrade as a response to the judgment and the grave suffering contained therein.[115] Naturally this reaction may not be representative and a minority event, possibly even a single incident. However, contesting evidence or a judgment as to its content is one thing. Laughing at the evidence and memory of victims of heinous crimes is something more shocking altogether. It gives a glimpse of the divides in society that Karadžić's actions and agenda has brought about. In the face of such adversity and poisoned minds, no witness accounts, no seemingly objective physical evidence which in turn has been tested by a team of forensic experts and by a court of law as to its probative value, is persuasive or acceptable. In other words, neither an appeal to empathy and humanity nor reason and basic logic are able to bridge the divisions. Judgments and forensic reports are no exceptions in this regard.

Acknowledgment of great suffering within the judgment, including references to the ongoing forensic work in Bosnia that continues to document and record the loss of life, may serve the victims, but it does not seem to get through to the (educated) Karadžić sympathisers.

However, properly investigated forensic evidence from mass graves, the presentation of such physical evidence, the testing of expertise, independence and impartiality of the accounts in court, is likely to result in more reliable findings even if they remain unpersuasive or unacceptable to some. In the Karadžić case forensic evidence helped confirm the crime base. It is well worth remembering that the information from forensic mass grave investigations has another purpose and does not only speak to a court of law. The work on the ground through organisations like ICMP will continue as there are "too many people who are still searching for their children's bones to bury"[116] and those forensic findings will have a value and meaning for family members and survivors that judgments like the Karadžić one cannot have. It offers them information on their lost loved ones and the return of their human remains. 
[1] Prosecutor v Karadžić, Public redacted version of Judgment issued on 24 March 2016, IT95-5/18-T, 24 March 2016, paras 6000-6010 [hereinafter Karadžić Judgment].

[2] See, for example, G. Delauney, Mixed reaction to Radovan Karadzic verdict in Bosnia. http://www.bbc.co.uk/news/world-europe-35897367, 24 March 2016 (accessed 20.04.16).

[3] R. Toe, Bosnian Media Split Over Karadzic Verdict.

http://www.balkaninsight.com/en/article/bosnian-media-split-over-karadzic-verdict-03-242016, 25 March 2016 (accessed 20.04.16).

[4] R. Hodzic, Post-Karadzic Bosnia and Herzegovina: The End of the Criminal Justice Era. https://www.ictj.org/news/karadzic-bosnia-herzegovina-criminal-

justice\#.VwvL wtXbgc.twitter, (accessed 12.04.16).

[5] D. Kostovicova, The Karadzic verdict: How the trial played out and what it means for Bosnia. http://blogs.lse.ac.uk/europpblog/2016/03/24/the-karadzic-verdict-how-the-trialplayed-out-and-what-it-means-for-bosnia/, (accessed 12.04.16).

[6] D. Jacobs, 6 Quick Thoughts on the Karadzic Judgment.

https://dovjacobs.com/2016/03/25/6-quick-thoughts-on-the-karadzic-judgment/, (accessed 12.04.16).

[7] Ibid.

[8]UN SC, Statute of the International Criminal Tribunal for the Former Yugoslavia (as amended on 17 May 2002), 25 May 1993, Art. 4 [hereinafter ICTY Statute].

[9] Ibid.

[10] Case Concerning the Application of the Convention on the Prevention and Punishment of the Crime of Genocide (Bosnia and Herzegovina v. Serbia and Montenegro), International Court of Justice, 26 February 2007, para 198.

[11] Yearbook of the International Law Commission, 1996, Vol. II, Part Two UN Doc A/CN.4/SER.A/1996/Add.1, p. 45, para 8 of the Commentary to Article 17.

[12]Prosecutor v Krstić, Appeals Chamber Judgment, IT-98-33-A, 19 April 2004, para 12; footnote omitted [hereinafter Krstić Appeal Judgment].

[13] Karadžić Judgment, para 477.

[14] Ibid. para 478.

[15] Ibid. paras 440-468.

[16] M. Klarin, The Tribunal's Four Battles. Journal of International Criminal Justice, 2(2) (2004) 546-557.

[17] International Criminal Tribunal for the Former Yugoslavia, Trial Judgment Summary for Radovan Karadžić.

http://www.icty.org/x/cases/karadzic/tjug/en/160324 judgement summary.pdf, 24 March 2016 (accessed 20.04.16).

[18] International Criminal Tribunal for the Former Yugoslavia, Rules of Procedure and Evidence, UN Doc IT/32/Rev. 42, Rule 94 bis [hereinafter ICTY RPE].

[19] For example, Prosecutor v Popović et al. Decision on Defence Rule 94 bis notice regarding Prosecution Expert Witness Richard Butler, IT-05-88-T, 19 September 2007.

[20] Karadžić Judgment, footnote 34.

[21] See, UNGA and UNSC, Fourth Annual Report of the International Tribunal for the Prosecution of Persons Responsible for Serious Violations of International Humanitarian Law Committed in the Territory of the Former Yugoslavia since 1991, (1997) UN Doc A/52/375 - S/1997/729; UNGA and UNSC, Sixth Annual Report of the International Tribunal for the Prosecution of Persons Responsible for Serious Violations of International Humanitarian Law Committed in the Territory of the Former Yugoslavia since 1991, (1999) UN Doc A/54/187 - S/1999/846; UNGA and UNSC, Seventh Annual Report of the 
International Tribunal for the Prosecution of Persons Responsible for Serious Violations of International Humanitarian Law Committed in the Territory of the Former Yugoslavia since 1991, (2000) UN Doc A/55/273-S/2000/777; and UNGA and UNSC, Eighth Annual Report of the International Tribunal for the Prosecution of Persons Responsible for Serious Violations of International Humanitarian Law Committed in the Territory of the Former Yugoslavia since 1991, (2001) UN Doc A/56/352-S/2001/865.

[22] Karadžić Judgment, paras 1090-1092.

[23] D. Rohde, Endgame: The Betrayal and Fall of Srebrenica, Europe's Worst Massacre Since World War II, Penguin, London, 2012.

[24] L. Silber, A. Little, The Death of Yugoslavia, Revised edn, Penguin, London, 1996, p. 350 .

[25] Karadžić Judgment, para 4943.

[26] E. Stover, G. Peress, The Graves. Srebrenica and Vukovar, Scalo, Zürich, 1998, pp. 319328.

[27] Prosecutor v Krstić, Appeals Chamber Judgment, IT-98-33-A, 19 April 2004.

[28] Prosecutor v Milošević, Witness Statement by Investigations Team Leader Dean Paul Manning, 24 November 2003.

[29] Ibid., para 4.

[30] International Commission on Missing Persons, Bosnia and Herzegovina. http://www.icmp.int/where-we-work/europe/western-balkans/bosnia-and-herzegovina/,

(accessed 29.04.16). The chamber cites the following mass grave sites in connection with the Srebrenica events as having been identified and/or exhumed by the BiHCMP and then ICMP: "Ravnice 2; Čančari Road 1, 2, 4-11, and 13; Hodžići Road 1, 2, 6, and 7; Liplje 1, 3, 4, and 7; Zeleni Jadar 1-4; Blječeva 1-3; Budak 1 and 2; Zalazje, Bišina, Bišina Cave, Sandići, and Potočari” (Karadžić Judgment, footnote 18858).

[31] Prosecutor v Blagojević and Jokić, Decision on Prosecution's Motion for Admission of Expert Statements, IT-0260-T, 7 November 2003, para 20.

[32] ICTY RPE, Rule 95.

[33] ICTY RPE, Rule 89(D).

[34] ICTY RPE, Rule 89 (C)

[35] Prosecutor v Blagojević (supra note 31).

[36] D. Manning (ICTY Investigator), Srebrenica Investigations. Summary of Forensic

Evidence Execution Points and Mass Graves' (Report, 16 May 2000).

http://abunodisceomnes.wellcomecollection.org/wp-content/uploads/2015/01/Manning-D.-

16-May-2000-Srebrenica-investigation-Summary-of-forensic-evidence-Execution-pointsand-mass-graves-ICTY-Investigator.pdf (accessed 22.06.16). The report can also be accessed via the ICTY's Court Records System: http://icr.icty.org/ for which a user registration is required.

[37] Prosecutor v Milošević, Decision on Admissibility of Prosecution Investigator's Evidence, IT-02-54-AR73.2, 30 September 2002, para 2(i)-(ii).

[38] Prosecutor v Blagojević (supra note 31), para 30.

[39] See, for example, Karadžić Judgment, paras 5579-5582.

[40] See Manning, supra note 36; D. Janc ICTY (Investigator), Update on the Summary of Forensic Evidence of the Graves and Surface Remains recovered related to Srebrenica (Report, 13 January 2012); and ICMP, Statement on Srebrenica killings of July 1995, 30 November 2007. Also relevant in this regard are ICMP Methodology Report on 2001-2008 DNA Process and ICMP report on DNA testing protocol, 14 February 2011. The judgment discusses Dean Manning's evidence in paragraphs 5579-5582, Dušan Janc's evidence in paragraphs 5583-5599 and ICMP in paragraphs 5558-5568.

[41] Ibid., para 5219. 
[42] Ibid., para 5153.

[43] Ibid., para 5219. See also Janc, supra note 40.

[44] Ibid. para 5213.

[45] Ibid., para 5221.

[46] Ibid., para 5254.

[47] Ibid., para 5255.

[48] Ibid., para 5261.

[49] Ibid., paras 5267 and 5268.

[50] Ibid., para 5271.

[51] Ibid., para 5273

[52] Ibid., para 5275.

[53] Ibid., para Para 5286

[54] Ibid., para 5342.

[55] Ibid., para 5342

[56] Ibid., para 5342

[57] Ibid., para 5346

[58] Ibid., para 5351

[59] Ibid., para 5351

[60] Ibid., para 5354.

[61] Ibid., para 5379.

[62] Ibid., para 5282.

[63] Ibid., para 5405-5408.

[64] Ibid., para 5411

[65] Ibid., para 5413.

[66] Ibid., para 5438.

[67] Ibid., para 5459.

[68] Ibid., para 5460.

[69] Ibid., para 5461.

[70] Ibid., para 5464.

[71] Ibid., para 5519.

[72] ICTY Statute, Art. 2, 4 and 5.

[73] ICTY Statute, Art.

[74] ICTY Statute, Art. 4(2)(d).

[75] Krstić Appeal Judgment, paras 15-16.

[76] Karadžić Judgment, parapara 5672.

[77] ICTY Statute, Art. 5(a),(b) and (h).

[78] ICTY Statute, Art. 2(a).

[79] Prosecutor v Karadžić, Decision on Accused's request for assistance of defence experts in the courtroom during testimony of seven prosecution expert witnesses, IT-95-5/18-T, 27

October 2011.

[80] Dušan Dunjić was also scheduled to testify in the Mladić trial but died the week before the hearing. He has also testified in the case of Popović et al. (See Sense Tribunal, Dusan Dunjic died of natural causes. http://www.sense-agency.com/icty/dusan-dunjic-died-ofnatural-causes.29.html?news_id=16834, 26 October 2015 (accessed 29.04.16). Furthermore, Dr. Dunjić had worked as a prosecution expert in three trials for crimes committed in Kosovo in 1998 and 1999 by Serbian political, police and military officials and former KLA commanders (ibid.).

[81] Karadžić Judgment, para 5516.

[82] Ibid., para 5517.

[83] Ibid., paras 5524-5525. 
[84] Ibid., para 5526.

[85] Ibid., para 5527.

[86] M. Klinkner, Proving Genocide? Forensic Expertise and the ICTY, Journal of International Criminal Justice, 6 (2008) 447-466, p. 454.

[87] Karadžić Judgment, para 5530.

[88] Prosecutor v Popović et al., Decision on Defence Rule 94 bis notice regarding Prosecution Expert Witness Richard Butler, IT-05-88-T, 19 September 2007, para 26.

[89] Karadžić Judgment, para 5531.

[90] Karadžić Judgment, para 5532.

[91] Ibid., para 5536.

[92] Ibid., para 5541.

[93] Ibid., para 5542.

[94] Ibid., para 5543.

[95] Ibid., paras 5545-46.

[96] Ibid., para 5547.

[97] Ibid., para 5547.

[98] Ibid., para 5554.

[99] Ibid., paras 5555 and 5557.

[100]ICMP, Statement on Srebrenica killings of July 1995 (supra note 40).

[101] Ibid., para 5566. Prosecutor v Karadžić, Decision on the Accused's Motion to exclude DNA Evidence, IT-95-5/18-T, 16 April 2013, paras. 6-7 and 9.

[102] Karadžić Judgment, para 5567.

[103] Ibid., para 5568.

[104] Ibid., para 5589.

[105] Ibid., para 5599.

[106] Sense Tribunal, What post mortems of Tomaisca victims showed. http://www.senseagency.com/icty/what-post-mortems-of-tomasica-victims-

showed.29.html?cat $\mathrm{id}=1 \&$ news $\mathrm{id}=16662,1$ July 2015 (accessed 29.04.16)

[107] Sense Tribunal, Blindfolded victims or fighters with 'Bandanas'. http://www.senseagency.com/icty/blindfolded-victims-or-fighters-with-

\%E2\%80\%98bandanas\%E2\%80\%99.29.html?cat id=1\&news id=17017, 20 April 2016 (accessed 29.04.16).

[108] Prosecutor v Šešelj, Judgment, IT-03-67-T, 31 March 2016.

[109] Prosecutor v Bemba Gombo, Judgment pursuant to Article 74 of the Statute, ICC01/05-01/08-3343, 21 March 2016.

[110] Rome Statute of the International Criminal Court (adopted 17 July 1998, as amended 16 January 2002) UN Doc A/CONF.183/9, Art. 69.3 (hereinafter Rome Statute)

[111] Rome Statute, Art. 69.4.

[112] Prosecutor v Lubanga Dyilo, Decision on the procedures for instructing expert witnesses, ICC-01/04-01/06, 10 December 2007, para 24.

[113] See, for example, A. Fulford, Reflections of a Trial Judge, Criminal Law Forum 22 (2011) 215-223.

[114] He faces 18 counts of war crimes and crimes against humanity allegedly committed while deputy military head of the Patriotic Forces for the Liberation of Congo.

[115] Hodzic, supra note 4.

[116] Ibid. 